\title{
Osman Bey’in Sevk ve İdare Anlayışının Stratejik Yönetim Kapsamında Değerlendirilmesi
}

\section{Evaluation of Osman Bey's Approach of Direction and Administration in the Scope of Strategic Management}

\author{
Uğur KESKİN ${ }^{1}$ \\ Hakan ÇANLI ${ }^{2}$ \\ Mustafa ERYAȘAR ${ }^{3}$ \\ Erkam Emin AYVAZ ${ }^{4}$
}

\begin{abstract}
ÖZ
Bu makalede, Osmanlı İmparatorluğu'nun kurucusu olan Osman Bey'in idare anlayışı ve faaliyetlerinin, günümüz çağdaş stratejik yönetim anlayışı bağlamında değerlendirilmesi amaçlanmaktadır. Bütün yönetsel uygulamaların olduğu gibi, Osman Bey'in gerçekleştirdiği faaliyetlerin de teorik düzlemde belirli karşlıkları bulunmaktadır. Makalede, Osman Bey'in yönetsel faaliyetlerinin, teorik bağlamda stratejik yönetim ile örtüşen yönlerini ortaya koyan değerlendirmelere yer verilmektedir. Nitel araştırma yöntemlerinden yorumlayıcı fenomenolojik yaklaşımın benimsendiği makalede, Osman Bey'in idari ve yönetimsel anlamdaki faaliyetleri, bilimsel nitelikli açıklamalara dönüştürülmüştür. Farklı tarihsel kaynaklarda yer verilmiş bulunan ve Osman Bey’in yönetim anlayışına ilişsin belirleyici nitelik taşıyan yönler ortaya konulmaya çalışııııștı. Büyüme ve bütüncül yaklaşıma dönük yönetsel faaliyetlerin neler olduğu belirlenmeye gayret edilmiştir. Osman Bey'in bütün bu uğraşıları, günümüz stratejik yönetim literatürü kapsamında ele alınarak çağdaş stratejik yönetim yaklaşımları ile olan ilişkisi değerlendirilmeye çalışılmıştır. Sonuç olarak Osman Bey, en genel çerçevede büyümeye odaklı bir yaklaşım ortaya koymuştur. Büyüme odaklı yaklaşımını destekleyen en belirgin unsur ise bütüncül bir bakış açısıyla olayları ele almasından ileri gelmektedir. Bütün bunların günümüz stratejik yönetim literatüründe teorik ve kavramsal bir arka planı bulunmaktadır. Söz konusu arka plan da bu makalede ele alınmıştır.
\end{abstract}

Anahtar Kelimeler: Osman Bey, Stratejik Yönetim, Büyüme Stratejisi, Bütüncül Yaklaşım.

\begin{abstract}
In this article, it is aimed to evaluate the administrative understanding and activities of Osman Ghazi, the founder of the Ottoman Empire, in the context of today's contemporary strategic management understanding. As with all administrative practices, the activities carried out by Osman Ghazi have certain equivalents on the theoretical level. The article includes evaluations that reveal the aspects of Osman Ghazi's managerial activities overlapping with strategic management in theoretical context. The article is structured on a systematic approach that includes the description of how Osman Ghazi experienced today's strategic management approaches. In the article in which the interpretive phenomenological approach, one of the qualitative research methods, was adopted, Osman Ghazi's administrative and managerial activities were transformed into scientific explanations. It has been tried to reveal the determinative aspects of Osman Bey's management approach, which are included in different historical sources. It has been tried to determine what the managerial activities towards growth and holistic approach are. All these efforts of Osman Bey were handled within the scope of today's strategic management literature and its relationship with contemporary strategic management approaches was tried to be evaluated. As a result, Osman Bey put forward a growth-oriented approach in the most general framework. The most prominent element supporting its growth-oriented approach is that it deals with events from a holistic perspective. All of these have a theoretical and conceptual background in today's strategic management literature, and this background is discussed in this article.
\end{abstract}

Keywords: Osman Bey, Strategic Management, Growth Strategy, Holistic Approach.

1 Prof. Dr., Anadolu Üniversitesi, İşletme Fakültesi, ugurkeskin@anadolu.edu.tr. ORCID: 0000-0003-2740-4120

2 Doktora Öğrencisi, Anadolu Üniversitesi, Sosyal Bilimler Enstitüsü, hakancanli@anadolu.edu.tr. ORCID: 0000-0002-2836-7029

3 Arş. Gör., Erzincan Binali Yıldırım Üniversitesi, Ali Cavit Çelebioğlu Sivil Havacılık Yüksekokulu, meryasar@anadolu.edu.tr. ORCID: 0000-0002-2934-6860

4 Öğr. Gör., Erciyes Üniversitesi, Havacılık ve Uzay Bilimleri Fakültesi, erkameminayvaz@erciyes.edu.tr. ORCID: 0000-0001-8213-5117 


\section{GIRIŞ}

$\mathrm{Bu}$ makale, Osmanlı İmparatorluğu'nun kurucusu Osman Bey'in sevk ve idare yaklaşımlarını ele almayı amaçlamaktadır. Osman Bey'in yürüttüğü yönetsel faaliyetlerin günümüz yönetim bilimi bağlamında belirli bir karşılığı bulunmaktadır. Özellikle de stratejik yönetim anlayışı ekseninde değerlendirilecek birtakım nitelikler ortaya koymaktadır. Yönetime konu olan her türlü uygulamada olduğu üzere, Osman Bey’in yürüttüğü faaliyetlerin de kuramsal bir temeli bulunmaktadır. Bu makalede, söz konusu kuramsal temel göz önünde bulundurularak Osman Bey'in yönetsel faaliyetleri, stratejik yönetim açısından değerlendirilmeye çalışılmıştır.

Tarihî bir kişiliğe dönük kaleme alınan ve stratejik yönetim literatürüne katkı sunmayı amaçlayan bu makalede, Osmanlı İmparatorluğunun kuruluş dönemi, özellikle de Osman Bey'in saltanatının başladığı zaman dilimi odak noktası olarak belirlenmiştir. Tarihî fırsatları yakalayabilme; enerjik, üstün zekâlı, birleştirici-bütünleştirici olma; gaza ve cihat bilinci; gazidervişlik; başarılı asker ve devlet adamları yetiştirme; teşkilatçılık, adaletlilik, stratejik kuşatma-çevreleme ve eş seçim özellikleri göz önünde bulundurulduğunda Osman Bey, stratejik yönetim alanı açısından araştırma ve incelemeye konu edilebilecek bir şahsiyet olarak belirginleşmektedir (Öztuna, 1994: 38; Cezar, 1962: 40).

Osman Bey'in stratejik başarılarının altında devletin konumu ve sosyal dinamiklerinin de önemli bir yeri bulunmaktadır. Bilecik, Kütahya ve Eskişehir dolaylarında kurulan beyliğin ilk yıllarında Osman Bey, yönünü Anadolu'daki Türk beyliklerinin aksine, Bizans topraklarına çevirmiş ve gaza politikası izlemiştir. Bu bağlamda elindeki fırsatları iyi bir şekilde değerlendirmiş ve ilk yıllarda bölgedeki Yenişehir ve Lefke Rum tekfurları ile iyi ilişkiler kurmuştur. Bölgedeki en güçlü Rum tekfuru olan İnegöl Tekfuru Nikolas ile ise bu iyi ilişkiler geçerli olmamıştır. Osman Bey döneminde yapılan savaşların büyük çoğunluğunu Bizans ile yapılan savaşlar oluşturmuştur (Cezar, 1962: 41-42; Öztuna, 1994: 41). Bu durum, ilerleyen süreçte diğer Türk beyliklerini de Osman Bey’in komutasında toplanmaya itici bir unsur olarak belirginlik kazanmıştır.

Bölgenin güçlü beylerinden Yavlak Arslan'ın ölümünün ardından Bizans topraklarına akınlar düzenleyen Ali Bey’in Bizans ile barış yapmasıyla birlikte akınların liderliğini Osman Bey almıştır. Bu akınlar, diğer gazileri ve beyleri de etkilemiş ve bunların kendisine katılmalarına ön ayak olmuştur. Osman Bey, kendisine katılan gazi ve beyler ile İznik'e ulaşmış ve bu beldeyi fethetmiştir. İznik'in ve yakın beldelerin fethi ile Osman Bey tüm Anadolu ve Bizans topraklarında ünlü bir bey hâline gelmiştir (Turnbull, 2012: 12). 
Osman Bey, genel yönetim anlayışı olarak adaletli, bütünleştirici olmayı ve büyümeyi amaçlamıştır. Osman Bey'in bu genel yönetim anlayışı ile günümüz stratejik yönetim yaklaşımları arasında bir ilişki kurabilmek, teorik öngörü bakımından mümkün görünmektedir. Bu nedenle, önemli tarihî şahsiyetler arasında yer alan Osman Bey’in yönetsel uygulamalarının, günümüz dünyasındaki karşılığının ortaya konulma çabası, anlamlı ve değerli bir çalışma olarak görünmektedir. Dolayısıyla aşağıdaki başlıklar altında, literatür incelemesi yapılmakta, kavramsal çerçeve üzerinde durulmakta ve Osman Bey'in stratejik yönetim teorileriyle ifade edilebilecek yönleri irdelenmeye çalışılmaktadır.

\section{KAYNAK İNCELEMESI}

Osman Bey’e ilişkin literatür incelendiğinde, yapılan çalışmaların genellikle kişilik özellikleri, isminin etimolojisi, adalet, hoşgörü, teşkilatlandırma ve fetih politikası konuları üzerinde yoğunlaştığı görülmektedir. Osman Bey, yaşam tarzı hâline getirdiği adalet ve hoşgörü anlayışını gündelik yaşamda uygulamaya dönük realist hamlelerde bulunmuş ve arkasında yüzyıllarca varlığını koruyan kalıcı bir miras bırakmıştır. Selçuklu Devleti’nin yıkılışı ve Osmanlı Beyliği’nin kuruluşu aşamasında yapmış olduğu birçok stratejik hamle olmasına rağmen, Osman Bey’in stratejik yönetim yaklaşımı kapsamındaki faaliyetleri literatürde incelenmemiştir.

Osman Bey'in adalet anlayışı o dönemde yönetimi altındaki insanlara etkili bir şekilde hissettirilmiştir. Âşık Paşa, Osman Bey’i “doğru adam, doğruluk eden adam ve adaletli adam” betimlemeleriyle ifade etmektedir (Aşıkpaşa, 1332: 23). Eskişehir'de kurulan pazara gelen gayrimüslim ahalinin mallarına el koyan Germiyanlıları bulup cezalandırmış ve adaletinin tüm insanlar için olduğunu göstermiştir (Cezar, 1962: 42). Bunun yanında pazarlarda etkili kurallar ile bir nizam oluşturmuştur. Bu nizam sayesinde Bilecik çevresinden Eskişehir pazarına gayrimüslim kadınlar dahi güven içerisinde gidip gelebilir olmuşlardır (Algül, 1999: 62).

İlgili literatür incelendiğinde, Osman Bey ve onun beylik yaptığı döneme ilişkin çok sayıda çalışma yürütüldügü görülmektedir. Söz konusu çalışmaların, yukarıdaki gibi betimsel olarak buraya aktarılması mümkün görünmemektedir. Bu nedenle Osman Bey ile ilgili olarak yürütülen bilimsel yayınları belirli başlıklar altında gruplandırmak gerekmektedir. Osman Bey'in yukarıdaki örneklerde aktarılan adalet yönünü öne çıkaran çalışmalar Cezar (1962) ve Algül (1999) tarafından kaleme alınmıştır. Stratejik yönetim açısından özel bir anlam taşıyan ve Osman Bey'in büyütme-büyüme yönüne vurgu yapan çalışmalar Öztuna (1994), İnalcık (1990; 1999), Kurtaran (2012), Cide (2014) ve Çakıray (2017) tarafindan; bütüncül yaklaşım hususuna ilişkin çalışmalar ise Cezar (1962), Danişmend (1971), İnalcık (1990), Çekiç (2018), 
Uzunçarşı1ı (1994), Barkan (2015) ve Bağcı (2020) tarafından yapılmıştır. Bütün bu incelemede edinilen kanaat, "Osman Bey" ve "stratejik yönetim" kavramlarının birlikte ele alındığı geçmiş dönem çalışmalara rastlanmamasından dolayı bu makalenin, ilgili alan açısından anlamlı katkı sağlayabileceğidir.

\section{YÖNTEM}

$\mathrm{Bu}$ makalede, yazılı tarih kaynaklarının ve bu kaynaklara bağlı olarak kaleme alınan ikincil kaynak eserlerin, geçmiş dönem gerçekliklerini olduğu gibi ve yansız bir biçimde yansıttıkları varsayımında bulunulmaktadır. Bu varsayıma dayanarak aşağıdaki önermeyi öne sürmek mümkündür.

Önerme: Geçmiş dönem yönetim uygulamalarının, günümüzün bilimsel teorileri arasında yer alan stratejik yönetim literatürü ile kurulacak olan benzerlikler aracılığıyla izah edebilmesi, ele alınan dönemin (Osmanlı'nın kuruluş döneminin) yönetsel faaliyetlerine dair işleyişin anlaşılmasını sağlayabilmektedir. $\mathrm{Bu}$ önerme doğrultusunda aşağıdaki araştırma sorusunun yanıtı aranmaya çalışılmaktadır.

Araştırma Sorusu: Belirli bir yönetimsel yapılanmanın kurucusu konumundaki Osman Bey gibi tarihsel kişiliklerin sergiledikleri yönetimsel yaklaşımlar, kendilerinden sonra gelen yöneticiler, hatta günümüz yöneticileri tarafından benimsenerek içselleştirilebilecek niteliklere sahip midir?

Geiger'e (2015: 124) göre, yorumlama ve değerlendirme eksenli olarak yürütülen fenomenolojik yöntemin gerçekten amaca götürebileceği, şu husus sayesinde anlaşılmaktadır: Tarih boyunca kalıcı olabilmiş görüşler, olayların özüne inen fenomenolojik yolla bulunabilmektedir. Açıklanan nedenlerden dolayı bu makalenin araştırma deseni olarak yorumlayıcı fenomenoloji türü benimsenmiştir. Creswell'e (2016: 77) göre fenomenolojik temelli araştırma ya da inceleme, belli bir kişi ya da grubun herhangi bir fenomen ya da kavrama ilişkin deneyimleri sonucu ortaya çıkan ortak anlamı ifade etmektedir. Dolayısıyla fenomenoloji sayesinde, incelemeye konu edilen fenomene dair edinilen kişisel çıkarımların, evrensel bir açıklama hâline getirilmesi amaçlanmaktadır.

\section{KURAMSAL VE KAVRAMSAL ARKA PLAN}

Aşağıdaki alt başlıklarda, makalenin teori ve kavram düzeydeki arka planını oluşturan çerçeve anlatımlara yer verilmektedir. 


\subsection{Kuramsal Çerçeve: Stratejik Yönetim}

Strateji kavramının kökeni hakkında literatürde fikir birliğine varılamamış olmasına karşın, daha çok askeri alanda kullanıldığı ve Antik Yunancada ordu için kullanılan "stratos" ve liderlik etmek, yönetmek anlamlarına gelen "agein" kelimelerinden oluşan "strategos" teriminden türediği görüşü ön plana çıkmaktadır (Evered, 1983). Stratejik yönetimin bilimsel bir disiplin olarak kabul görmesi görece yakın bir tarih olan yirminci yüzyılın ortalarına denk gelmekle birlikte, Mintzberg ve Quinn (1991), stratejinin yönetimsel bir beceri olarak nitelendirilmesinin MÖ beşinci yüzyılda yaşayan Perikles dönemine dayandığını ifade etmektedir. Tarihi kaynaklarda, Perikles'in baş stratejist anlamında da kullanılan "strategos" unvanını MÖ 460 ile MÖ 429 yılları arasında kesintisiz olarak 30 yıldan fazla taşıyarak, Atina Şehir Devleti'ne stratejik anlamda liderlik ettiğine yer verilmektedir (Evered, 1983). MÖ dördüncü yüzyılda yaşayan bir başka Antik Yunan düşünürü olan Ksenofon (Xenophon) ise yapılması gereken iş hakkında yeterince bilgi sahibi olmanın iyi bir strateji geliştirilmesinin ön koşulu olduğunu ifade ederek stratejinin önemine vurgu yapmaktadır (Cummings, 1993).

Strateji ve stratejik yönetim kavramlarına ilişkin ilk fikirlerin Antik Yunan düşünürleri tarafından ortaya konulmasına karşın, stratejik yönetimin ayrı bir bilimsel disiplin olarak kabul görmesi ancak İkinci Dünya Savaşı sonrasında yapılan çalışmalarla mümkün olmuştur (Bracker, 1980). Harvard Üniversitesi'nde 1920'li yıllarda verilen “Yönetim Politikaları" dersinde stratejik yönetim konularının anlatıldığına vurgu yapan Barca (2005), alanın 1960'lar sonrasında çok sayıda araştırmacının ilgisini çekmesi ve yapılan çalışmaların sayısındaki artış ile birlikte ayrı bir bilimsel disiplin özelliğini kazandığını ifade etmektedir. İkinci Dünya Savaşı yılları sonrasında yapılan çalışmalarla birlikte strateji ve stratejik yönetim kavramlarına ilişkin günümüzde kabul gören tanımların yapıldığı ve alana ilişkin literatürün şekillenmeye başladığı kabul edilmektedir (Ferreira vd., 2014). Söz konusu tanımlama girişimleri bağlamında Drucker (1954) stratejiyi, mevcut bir durumun analiz edilmesi ve gerekli hâllerde bu durumun değişmesi için karar alarak eylemlerde bulunulması şeklinde tanımlarken; Chandler (1962), bir örgütün uzun vadeli hedeflerinin belirlenmesi, örgütü bu hedeflere götürecek olan kararların alınması ve alınan kararların uygulanması süreçlerinde etkili olan bir unsur olarak ifade etmektedir. Stratejiyi bir öğrenme süreci olarak ele alan Mintzberg (1967), stratejik kararları örgütteki yöneticinin öğrenme sürecine bağlı olarak örgüt içerisinde yapısal ya da ticarî farklı alanlarda alınan kararlar bütünü olması açısından ele almaktadır. Diğer yandan stratejiyi rekabet avantajı elde etmenin kilit unsuru olarak ele alan Porter (1985), stratejiyi, örgütlerin sektör içerisinde rekabet avantajı elde etmek için rakipleri karşısında kendilerini pazarda konumlandırmalarına 
ilişkin olarak saldırı ya da savunmaya yönelik alınan kararlar olarak izah etmektedir. Yaklaşık 60 yıldır stratejik yönetim alanında çok sayıda bilimsel çalışma yapılmıştır. Yönetim bilimleri alanında oturmuş bir literatüre sahip olan stratejik yönetim düşüncesinde zaman içerisinde bir dizi değişimler olmuştur (Barca, 2009). Bu değişimlerin yeni teorik arayışlardan ziyade, çevresel koşullarda meydana gelen değişimlere bağlı bir biçimde gerçekleştiği öne sürülmektedir. Bu açıklamadan yola çıkılarak, farklı dönemlerde farklı çevresel koşullar altında şekillenen stratejik yönetim yaklaşımlarının daha objektif biçimde incelenebilmesi için ilgili dönemin koşullarının detaylı olarak araştırılması ve anlaşılmasının son derece önemli olduğu sonucuna varılmaktadır.

\subsection{Kavramsal Çerçeve}

Makale kapsamında yapılan analizler neticesinde elde edilen bulgulara geçmeden önce, analiz sürecinde yararlanılan stratejik kavramların açıklanması gerekmektedir. Söz konusu gereklilik doğrultusunda, aşağıda, büyüme stratejileri ve bütüncül yaklaşıma ilişkin literatürde yer alan tanım ve görüşlere yer verilmektedir.

Büyüme Stratejileri: Örgütlerin faaliyet gösterdikleri alanda mevcut pozisyonlarını korumak, kendilerini geliştirmek ve gelirlerini artırmak amacıyla mevcut kapasitelerini ve becerilerini kullanarak büyüme eğiliminde olabileceklerini ifade eden Ülgen ve Mirze (2020), temel büyüme stratejilerini, "Mevcut İşin Tanımını Değiştirerek Büyüme” ve "Faaliyetlerin Hız ve Etkililiğini Değiştirerek Büyüme” olmak üzere iki ana başlıkta toplamaktadır. Pazardaki rakipleri ile rekabet edebilmek için örgütlerin büyüme stratejisi geliştirmelerinin önemini vurgulayan Rothaermel (2016), örgütlerin maliyetleri en aza indirmek, kârlarını artırmak, pazardaki rekabet gücünü artırmak, faaliyet riskini azaltmak ve yönetimsel motivasyonu artırmak için büyüme stratejilerine gereksinim duyduklarını ifade etmektedir.

Büyüme stratejilerinin geliştirilmesi kadar önemli olan bir diğer husus da büyüme stratejilerinin başarılı bir biçimde uygulanabilmesidir (Kapur vd., 2005). Büyüme stratejilerini başarılı bir biçimde oluşturmak ve uygulamaya geçirmek isteyen örgütlerin öncelikle güçlü ve zayıf yönlerini doğru bir şekilde tespit ederek iç çevre analizi yapması ve ardından pazardaki firsat ve tehditleri belirlemek üzere dış çevre analizini gerçekleştirerek uygulanabilir ve örgütün tüm iç paydaşları tarafından benimsenecek bir büyüme stratejisi geliştirmesi gerekmektedir. Büyüme stratejilerinin başarıya ulaşması hâlinde örgütlerde, nicel büyüme (kaynak büyüklüğü, varlık büyüklüğü ve kapasite kullanımı) ve nitel büyüme (örgütsel unsurların kalitesinde artış meydana gelmesi) olmak üzere iki yönlü bir büyüme gerçekleşmesi beklenmektedir (Ülgen ve 
Mirze, 2020). 1980'lerdeki şirket evlilikleri ve devralmaları, örgütlerin büyümesi gerekliliği teorisi için ampirik bir kanıt olarak görülmeye başlamıştır. Piyasa analistleri de bu tür evliliklerin ne denli arzulanır olduğu konusunu sıklıkla gündeme getirmişlerdir (Nelson, 2018: 103).

Bütüncül Yaklaşım: Rasyonel stratejik yönetim yaklaşımlarına göre örgütler, stratejik planlama süreçlerinde çevre analizi yaparken, faaliyet alanlarında yer alan diğer örgütlerin oluşturduğu çevreyi bir bütün olarak ele alan bütüncül (holistik) bakış açısına sahiptirler (Ülgen ve Mirze, 2020). Yönetim alanında daha bütüncül bir anlayışın ortaya çıkmasının 1972 yılında Bertalanffy tarafından geliştirilen sistem yaklaşımına dayandığını ifade eden Koçel (2018), bütüncül yaklaşımı olayların, durumların ve meydana gelen gelişmelerin analiz edilmesinde yararlanılan bir metot, bakış açısı ya da düşünce tarzı olarak ifade etmektedir.

Örgütlerin stratejilerinin başarıya ulaşmasında iyi bir strateji kadar, stratejinin örgütün tüm paydaşları tarafindan net bir biçimde anlaşılmasının ve benimsenmesinin de son derece önemli olduğunu ifade eden Keçecioğlu (2008), strateji kavramının ele alınmasında bütüncül bir yaklaşımı ön plana çıkartmaktadır. Örgütün iç paydaşlarının öneminin vurgulandığı bu açıklamaya ek olarak büyüme stratejilerinde de yer verilen iç ve dış çevre analizleri yapılırken, örgüt ile aynı pazarda yer alan diğer örgütlerin oluşturduğu dış çevrenin de bütüncül yaklaşım kapsamında stratejilerin geliştirilmesi ve uygulanması süreçlerinde göz önünde bulundurulması gerektiği dile getirilmektedir. Aşağıdaki anlatımlarda, Osman Bey dönemindeki yönetsel uygulamalar büyüme stratejileri ve bütüncül yaklaşım bağlamında ayrıntılı olarak incelenmektedir.

\section{ANALIZ: OSMAN BEY DÖNEMI'NDEKI YÖNETSEL UYGULAMALARIN STRATEJIK YÖNETIM KAVRAM VE TEORILERİ İLE IZAH EDÍLEBİLECEK YÖNLERI}

Osman Bey, yürüttüğü yönetsel faaliyetler sayesinde, Batı Anadolu Bölgesi’nde aynı inanış ve değerler ile müttefik olarak hareket edebilecek potansiyele sahip Türkmen beyliklerini, kendi beyliğinin uhdesine almıştır. Bu başarısındaki kilit unsur ise sahip olduğu kişisel karizma olmuştur. Kenetlenmelerini sağladığı müttefik unsurların da katkısıyla gerçekleştirdiği hızlı fetihler ve kurduğu düzen, imparatorluğun temelini atmış ve sonradan imparatorluğa adının verilerek padişah vasfı ile anılmasını sağlamıştır (Turgut, 2016: 98). Yöneticilerin öngörü (feraset) sahibi olması gerektiği vurgusu, stratejik yönetim yazınında başat bir konu olarak öne çıkmaktadır. 
Aşağıdaki alt başlıklarda, Osman Bey'in yönetsel faaliyetlerinin stratejik yönetim ekseninde değerlendirildiği aktarım, anlatım ve değerlendirmelere yer verilmektedir. Fakat bu alt başlıklar, bunlara konu olan kavramlar arasında mutlak ayrımlar ortaya koyma amacıyla değil, analitik çözümleme yapabilmek için oluşturulmuştur. Örneğin Osman Bey’in büyüme anlayışı ile bütüncül yaklaşımı, birbirinden bağımsız yönler taşımamakta; aksine birbirini destekler nitelikler ortaya koymaktadır.

\subsection{Osman Bey’in "Büyüme" Odaklı Yaklaşımının Stratejik Yönetim Bağlamında Değerlendirilmesi}

Chandler tarafından formüle edilen ve "Yapı, stratejiyi takip eder." şeklinde ifade edilen anlayışa göre örgütler (özellikle kâr amacı güden örgütler), öncelikle ölçek büyütme, daha sonra çeşitlendirme, üçüncü aşamada ise bölgeselleşme şeklinde gelişme kaydetmektedirler. $\mathrm{Bu}$ açıdan değerlendirildiğinde Osman Bey’in, “büyüme” anlayışı, çağdaş literatürdeki stratejik yönetim anlayışı ile uyumlu görünmektedir. Nitekim Osman Bey, büyüme stratejisinin semeresini almış, yaklaşık 400 çadırlık yani en çok 4000 kişilik Kayı Boyu’nun Ertuğrul Gazi öldügünde en fazla 4.800 kilometrekare olan topraklarını (Öztuna, 1994: 37), 1324 yılında öldüğünde 16.000 kilometrekareye çıkarmış (Öztuna, 1994: 45), bu sayede de çevresinde saygın bir beylik hâline getirmiştir.

İnalcık (1999: 37) da bu büyümenin ana unsurlarından birinin Oğuzların Anadolu'ya yaptıkları yoğun göç olduğunu belirtmektedir. Ayrıca yine İnalcık’ın vurguladığı Türk-İslâm gaza hareketi ile Batı ve Güney Anadolu'nun ekonomik merkez olarak dünya ticaret yolları üzerindeki önemini artırması, söz konusu büyüme sürecine katkı sağlayan bir husus olarak ön plana çıkmaktadır.

Nüfus potansiyeli ve cihat anlayışının sürüklediği göçebe grupların Bizans yaylalarına mevsimlik göçleriyle başlayan Bizans aleyhine yayılma, ganimet seferleri ile desteklenmiş, başarılı liderlerin beylikler kurmasıyla devam etmiş ve ortaya çıkan politik ve ekonomik eğilimler yeni amaçlara odaklanarak son hâlini almıştır (İnalcık, 1990: 334). Osman Bey’in “gaza" anlayışı, "stratejik niyet” ya da "vizyon” kavramlarıyla ele alındığında, aslında uzun vadeli amacı devlet yönetimi açısından, nüfus ihtiyacı ile de uyumlu bir toprak genişletmeyi öngören politika olan büyüme stratejisini ifade etmektedir.

Osman Bey, babası Ertuğrul Gazi'nin yerine geçtiğinde aşiret, Candaroğulları Beyliği'ne, Candaroğulları Beyliği Selçuklu Devleti'ne, Selçuklu Devleti ise İlhanlılara tabiydi. Bu dönemde, Moğollar en belirleyici unsur olmakla birlikte hâkimiyetleri nispeten zayıflamıştı. 
Selçuklu Devleti'nin 1308 yılında ortadan kalkmasıyla, beylikler de doğrudan İlhanlı Devleti'ne bağlanmışlardır. Merkezî otoritenin zayıf olduğu bu dönemde özellikle batı uçlardaki beylikler, bulundukları bölgelerde yavaş yavaş hâkimiyet kurmaya başlamıştır (Cide, 2014: 101). Bağımlılık ilişkisi bakımından piramidin en alt basamağı olan üçüncü basamakta yer alan Osman Bey, kararlı bir büyüme stratejisi sayesinde ve en uygun zamanda en uygun hamleleri planlayarak bağımsız bir beylik olmayı başarmış, zaman içinde de büyüme amacını gerçekleştirmiştir.

Osman Bey, 1284 yılında, yerel ve nispeten önemsiz olarak değerlendirilen Ermenibeli çatışmasından itibaren İnegöl Tekfuru'nun bölgedeki nüfuzunu kırma gayretinden ödün vermemiştir (Güler, 2019: 60-61). Dolayısıyla Osman Bey, İnegöl Tekfurluğu'nu fethedene kadar baskın bir strateji izlemeye gayret etmiştir. Büyüme amacı ekseninde şekillenen yönetsel anlayışının tezahürü olarak, mevzii kazanımlarıyla yetinmeyip, kazanımları sürdürülebilir kılacak girişimlerde bulunmuştur.

Osman Bey, Türk devletlerinden gelen köklü bir siyasî kültürün mirasçısı olarak diğer Türk beylerini de kendisine bağlamış ve ilerideki dönemde kurulacak imparatorluğun temellerini atmıştır. Zamanla güçlenen ve büyüyen Osmanlı Devleti, kuruluş dönemindeki sağlam teşkilât yapısı ve başarılı sistemleri sayesinde büyük bir imparatorluk hâline gelmiştir (Kurtaran, 2012: 258). Osmanlı Devleti'nin küçük bir uç beyliğinden imparatorluğa dönüşmesinin temelleri ve niteliği üzerine birçok tez ortaya konmuştur. Herbert Adams Gibbons'un dinî dönüşüm hipotezi ile bunun tam karşıtı olarak Fuat Köprülü’nün İslam ve Türk faktörlerine dayanan açıklaması ilk yaklaşımlardır. Bunun yanında Köprülü’ye katılan Paul Wittek, gaziler ve onların değerler sistemine odaklanmış, bu yaklaşım 1980'lerden itibaren diğer Osmanlı tarihçileri tarafından geliştirilmiştir (Çakıray, 2017: 7). Tarihsel gelişim sürecine ilişkin bu görüşlerden ziyade, Osman Bey'in genel yönetsel anlayışına stratejik yönetim açısından bakıldığında, Chandler'ın örgütsel büyümeyi açıklayan aşamalarından “ölçek büyütme” kavramı ile benzer bir görünüm sergilediği çıkarımı yapılabilmektedir.

Osmanlı Beyliği’nin kuruluş ve yükselişi döneminde geçerli olan iki büyük değerin, İslam dini ve Orta Asya Türk ananesi olduğu kaynaklardan anlaşılmaktadır. Bu unsurlar devletin kuruluşunun ana unsuru olan gücü ortaya çıkarmış ve bu erk, devletin kurularak gelişmesine katkı sağlamıştır (Cide, 2015: 105). Söz konusu değerlerin yanı sıra, bölgenin, giderek ekonomik bir cazibe merkezi hâline getirilmesi, ilişkili diğer unsurlara karşı mukayeseli bir üstünlüğü de beraberinde getirmiştir. 
Osman Gazi, 1288'de Karacahisar'1 fethederek uçta sancakbeyliğine yükselmiş, bağımsız olmasa da daha serbest hareket edebilecek hâle gelmiştir (Güler, 2019: 61, 62). 1288-1299 döneminde Osman Bey, Selçuklu sultanına haraç ödeyen yerel tekfurları (Göynük, Gölpazarı, Bilecik, Yenişehir, İnegöl, Yarhisar tekfurları) ortadan kaldırmış; Bitinya'da Bizans topraklarına karşı gaza faaliyetine başlamıştır (Başar, 2018: 37-38). Gaza, fetih ve cihat gibi dinî güdüler, Osman Bey’in büyüme odaklı yönetim anlayışına katkı sağlamıştır. İlerleyen y1llarda, coğrafî ve lojistik açıdan kilit nitelikteki beldelerin ele geçirilmesi, büyüme idealini canlı tutan bir unsur olmuştur.

1302'de Bizans velî ve tekfurlarından oluşan birleşik bir kuvveti, Koyunhisar Savaşı'nda yenilgiye uğratan Osman Bey, Bizans'1 siyasî ve askerî anlamda tehdit edebilecek yeni bir güç olarak ortaya çıkmış ve savaş sonrasında da genişleme politikasını sürdürmüştür. Yenişehir'i ele geçirerek burayı hareket üssü yapmış ve tüm faaliyetlerini İznik ve Bursa üzerine yönlendirmiş, buraları sürekli abluka altında tutmuştur (Başar, 2018: 38-40).

Osman Bey’in genel yaklaşımı, bölgedeki Bizans savunmasının sıklet merkezlerini teşkil eden müstahkem mevkileri doğrudan ele geçirmek yerine, lojistik olanaklarını kontrol altında bulundurmak şeklindedir. Bu yaklaşım doğrultusunda öncelikli olarak, kritik geçit noktaları üzerinde hâkimiyet sağlamıştır. Bu anlayış sayesinde, Bizans yerleşim bölgeleri ile askerî yönden değer taşıyan kaleler arasındaki ulaşımı sınırlandırmıştır. Kritik faktör analizine benzer bir anlayışla, avantajlı konuma sahip bulunan karşıt unsurları etkisiz kılarak tecrit edilmiş bir hâle getirdiği yerleşim birimleri ve kritik coğrafyaları sistematik bir biçimde topraklarına katmıştır.

Aslında Osman Gazi hem Marmara hem de Karadeniz'e ulaşarak Bizans'1 sıkıştırmak istemiştir. Nitekim onun bu stratejisi sürdürülerek Rumeli'ye geçişle birlikte İstanbul'un çok yönlü sıkıştırılmasının adımları hızlanmaya devam etmiştir. Bu bağlamda Fatih Sultan Mehmet'in sonuçlandırdığı İstanbul fethi, Osman Gazi'nin stratejisi ile temellendirilmiştir (Algül, 1999: 64). Osman Bey döneminin önemli kişilerinden biri Umur Bey’dir. Osman Bey, Sakarya-Bolu hattındaki fetihlerini Umur Bey’in oğlu Ali Bey ile beraber yapmış, Umuroğullarıyla birleşmeleri Üsküdar'a kadar olan yerlerin hızla fethedilmesini sağlamıştır (Turgut, 2016: 95).

Osman Bey’in uzun vadeli hedefi Bizans'a, özellikle de İstanbul'a doğru yönelmek olmuştur. Taktik düzeyde gerçekleştirdiği, "kama” şeklindeki Bizans topraklarını ve unsurlarını elde etme çabası, stratejik bakımdan anlamlı bir rekabet üstünlüğü elde etmesini sağlamıştır. Bu husus, salt askerî taktik/teknik uygulama gibi gözükmektedir. Fakat bu uygulama, manevî 
açıdan insanlar için derin anlamlar ifade eden fetih, şehitlik, gazilik gibi kavramlar ile de desteklenmiştir. Stratejik yönetim anlayışında "vizyon, misyon, değerler" şeklinde sıralanan üçleme, genelden özele doğru birbirini desteklemektedir. Osman Bey’in uygulamaları açısından büyüme vizyonu, üstlendiği batıya yönelme misyonu ile desteklenmiş, nihayetinde değerler bütününü oluşturan manevî unsurlar ile de uzun erimli amaçlara ulaşmayı kolaylaştırmıştır.

\subsection{Osman Bey’in Faaliyetlerinin "Bütüncül Yaklaşım” ile Değerlendirilmesi}

Osmanlı İmparatorluğu'nun klasik dönem yönetim anlayışı döneminde yaşayan ve bu dönemi çok iyi yansıtan Kınalızade Ali Efendi (2010), Devlet ve Aile Ahlakı adlı eserinde bütüncül yaklaşımı ile ön plana çıkmaktadır. Osmanlı'nın cihan imparatorluğu hâline geldiği bir dönemde böylesi bir görüşe sahip olmak belki de aksi düşünülemeyecek bir durum iken, Osman Bey gibi kuruluş döneminde hüküm süren bir hanedan üyesi için oldukça vizyon sahibi olmayı gerekli kılmaktadır. Dolayısıyla, Osman Bey’in İslam dininin birleştiriciliğinden de yola çıkarak Müslümanlar ile gayrimüslimlere karşı adalet anlayışıyla yaklaşımı, onun kavrayıcı ve kuşatıcı yönetim tarzı ile ilintili bir biçimde izah edilebilecek bir durum olarak görünmektedir.

Fuat Köprülü’ye göre, Gibbons’un iddia ettiği gibi Ertuğrul Bey’in aşiretleri, dört yüz çadırdan oluşan devlet yönetimi ve siyaset kültüründen yoksun bir topluluk değildir. Osmanlı idare teşkilâtı Selçuklu ve İlhanlılar'ın devlet idare geleneklerine göre düzenlenmiştir. Devlet işlerinde Türk aristokrasisi ve memurları kullanılmıştır (Barkan, 2015: 9). Köklü bir geçmişe dayanan yönetim anlayışını mevcut duruma, hatta geleceğe taşıma çabasının, çağdaş stratejik yönetim düşüncesi göz önünde bulundurulduğunda bütüncül bir bakış açısına sahip olmakla izah edilmesi mümkündür.

Cihat ve akınların başarıları ile liderlerin etrafında toplanılmış ve birbirine bağlı bir sosyal bütünleşme oluşmuştur. Selçuklu'nun içinde bulunduğu karışıklık da yiğit savaşçıların ve Moğol hâkimiyetine girmek istemeyen Türkmen aşiretlerin Osman Bey’e katılmasını sağlamıştır (Cezar, 1962: 46). Türkmen birlikleri ünlü Türk ok ve yaylarının üstünlüğü yanında idare yapıları ve bir arada uzun zamandan beri savaşmalarından kaynaklanan profesyonellikleri nedeniyle çok daha başarılıydı (İnalcık, 1990: 335-337). Cihat, gaza ve fetih gibi dinî temelli unsurlar, birçok yönetimsel konuda olduğu gibi bütüncül yaklaşımın kayda değer bir yönünü teşkil etmektedir. Ayrıca, yukarıda vurgulanan ve devlet yönetimi geleneği açısından ifade edilen bütüncül anlayış, muharebe etkinliği açısından ok ve yayların kullanımı ile bu alanlardaki profesyonellik unsurlarının her birini kapsamaktadır. 
Osman Bey döneminde sağlanan adalet ve hoşgörünün, ilerleyen yıllarda şehirlerin fethinde de önemli bir etkisi olmuştur. Adalet ve güven kavramlarına sığınarak birçok Türk obası bölgeye göç etmiş ve Osman Bey’in yanında fetihlere katılmışlardır. Bunun yanında Orhan Gazi döneminde İznik'in fethinde şehre gelen gayrimüslimler Osman Bey'in adalet ve hoşgörü anlayışını İznik’te duyurarak fethin kolaylaşmasına ön ayak olmuşlardır ve ilerleyen fetihlere yardımcı olmuşlardır (Danişmend, 1971: 18). Müslüman-gayrimüslim gibi toplumsal kesimler arasında ayrım gözetmeyen uygulamalar, beyliğin evrensel, kuşatıcı ve bütüncül yönelimine katkı sağlayan hususlar olarak dikkat çekmektedir.

Osmanlı'nın kuruluş döneminde Anadolu, değişik inanç, kültür ve geleneklerin kesiştiği bir bölgeydi. Bu bakımdan dinî, fikrî ve kültürel açıdan eklektik bir yapıya sahipti. Türklerin Anadolu'ya göçüyle gelen derviş, fakih ve mutasavvıflar, Anadolu'da Bektaşîlik, Mevlevîlik, Rufaîlik, Kâzerûnîlik, Kadirîlik, Halvetîlik, Haydarîlik ve Kalenderîlik gibi tarikatlar ortaya çıkarmıştır. Bu tasavvufî zümreler hem Anadolu'nun İslamlaşmasında ve Türkleşmesinde büyük katkı sağlamış hem de teşkilatları ile fetihte önemli roller üstlenmişlerdir (Bağcı, 2020: 241).

Tarikatlar, Osman ve Orhan Gazi'ye destek vererek tekkeleriyle Osmanlı Devleti'nin oluşumunda bazen bir asker ocağı, bazen bir karakol, bazen bir keşif kolu, bazen de ilim yuvası olarak hizmet vermişlerdir (Algül, 1999: 63). Osmanlı Devleti de kuruluş sürecinde maddî ve manevî olarak bu gruplardan faydalanmış, bölgede siyasî ve iktisadî birliği bu suretle sağlamıştır (Bağc1, 2020: 248). Osman Bey'in, dönemin nüfuzlu isimlerinden Vefaî şeyhi Edebali'nin kızı ile evliliği her iki tarafa da katkı sağlamıştır. Bu birliktelikten Vefaîler Osmanlı nezdinde kabul görerek, Osman Bey ise geniş bir etki ağına sahip Şeyh Edebali'nin nüfuzundan destek alarak fayda görmüştür (Çekiç, 2018: 258; Uzunçarşıll, 1994: 105).

Osmanlı İmparatorluğu'nun kuruluş döneminde, gaza anlayışına sahip beyliklerin, Selçuklu Devleti'nin zayıflama ve yıkılması sonrasında gaza misyonunu üstlenmek için birbirleriyle rekabete giriştikleri öne sürülebilir. Bizans'a karşı zafer kazanmanın bu rekabette belirgin bir fark yaratabileceği düşünüldüğünde Osmanlı Beyliği’nin Bizans'a yakınlığı, bu bakımdan coğrafî avantaj sağlamıştır (Cide, 2015: 108). Bu bağlamda, gaza anlayışı Osmanlı Beyliği’nin kuruluş ve yükselişinde önemli bir rol oynamıştır. İnanç sisteminin yapısı itibariyle gaza, gayrimüslimlere karşı uygulanmakta, gayrimüslim bölgelere İslamiyet'in ulaştırılmasını hedeflemektedir. Gaza anlayışı Anadolu'nun dağınık olarak ifade edilebilecek siyasî ve sosyal yapısı içerisinde beyliklerin kurulması, güçlenmesi ve kontrol alanlarını genişletmelerinde birleştirici ve sürükleyici bir rol oynamıştır. Batı Anadolu'daki Türkmen beyliklerinin, aynı 
inanış ve değerler sisteminin hâkim olduğu bir dünyayı oluşturmaları, ittifak içinde hareket etmelerine belirgin katkılar sağlamıştır (Turgut, 2016: 96). İyi savaşçılar, doğal olarak gazada başarı gösteren beylerin etrafında toplanma eğiliminde oldukları için gaza anlayışı, Anadolu beylikleri arasındaki liderliğin dolayısıyla da bütünleştiriciliğin ana unsuru hâline gelmiştir (Cide, 2014: 101). Ayrıca gaza ruhu Anadolu Türkmenlerini ayakta tutan bir güç olmuştur. Gazadan elde edilen ganimet bir gazi için helal kazanç, hatta kazançların en meşrusu olarak değerlendirilmiştir (İnci, 2014: 2).

Belirli bir unsurun, güç merkezi hâline gelmesi, diğer unsurları olumsuz yönde etkilemektedir. Güce katkı sağlayan unsurların Osmanlı Beyliği’nde temerküz etmesine bağlı olarak, Osmanlı'nın hâkimiyeti de meşru görülmeye başlanmıştır. Bu ise coğrafî yakınlığa bağlı olarak Anadolu beyliklerinin kuruluş döneminden başlayarak Osmanlı'ya katılmalarını sağlamıştır. Yukarıdaki anlatımlardan da açık bir biçimde anlaşılabileceği üzere, Anadolu beyliklerinin, Osmanlı Beyliği'ne tabi olmalarında inanca dayalı faktörler, belirleyici bir rol üstlenmiştir.

Ertuğrul Gazi, Moğol hâkimiyetinden sonra çevredeki tekfurlarla iyi ilişkiler kurmaya başlamıştır. Bu politika, Osman Gazi tarafından da sürdürülmüştür. Bu olumlu ilişki her iki taraf için de avantajlar sağlıyordu. Ayrıca Karacahisar ile Bilecik tekfurlarının Selçuklu Devleti'ne tabi olmaları da Osman Gazi'nin Selçuklu Devleti’ne bağlı kaldığı döneme kadar olumlu ilişkileri destekleyen bir unsur olmuştur. Dolayısıyla dostane ilişkiler, çıkar ilişkilerine de katkı sağlamıştır (Güler, 2019: 60). Osmanlıların kuruluş ve yükseliş devirlerindeki ilerlemelerinde, elde edilen topraklardaki gayrimüslim halkın, Osmanlı idaresini benimsemeleri belirgin bir etmen olarak öne çıkmaktadır. $\mathrm{Bu}$ ise çokça bilinen iki nedenden kaynaklanmaktadır. Birincisi Osmanlıların, fethedilen bölgelerde, hiçbir ayrım gözetmeksizin tüm insanlara karşı hoşgörülü ve adaletli bir yaklaşım sergilemelerine dayanmaktadır. İkinci neden ise yüzyıllardır sürmekte olan Bizans hâkimiyetinin; yönetsel, hukukî ve ekonomik açıdan sürdürülebilir olmaktan uzaklaşmasıdır.

Osman Bey’in, beyliğin ilk yıllarında Bizans tekfurları ile iyi geçindiği anlaşılmaktadır. Osman Bey, siyasî ve askerî amaçlar taşısa da zaman zaman gayrimüslim komşularının düğününe giderek onlara hediyeler de götürmüştür. Ayrıca Osman Gazi’nin çevredeki gayrimüslimler ile iyi komşuluk ilişkileri kurduğu da bilinmektedir (Başar, 2018: 42-43). Osman Bey, kendisine bağlılık ve vefa gösteren gayrimüslimlere adaletle hükmetmiş, fethettiği bölgelerin halkının can ya da mal güvenliğini ihlal etmemiştir (Öztuna, 1994: 17). Bu tutumu sayesinde yeni fethedilen yerlerde fazla tepki ile karşılanmamış; hatta topluluklar, 
kendiliğinden Osmanlı egemenliği altına girmiştir. Harmankaya Tekfuru Köse Mihal Bey’in 1313'te Müslüman olarak Osman Bey’e katılması (Uzunçarşı1l, 1994: 110) ve bazı gayrimüslimlerin, kuşatmanın sürmekte olduğu süreçte, şehre gelerek İznik’teki soydaşlarına teslim olmalarını ögütlemeleri (Algül, 1999: 62) bunun en anlamlı̈ örneklerini teşkil etmektedir.

Osman Bey’in yönetimsel yaklaşımı, Orhan Bey’e vasiyet ve nasihatlerinden yola çıkıldığında büyük ölçüde anlaşılabilmektedir. Çeşitli kaynaklara göre, oğlu Orhan Bey’e İslam'a hizmet etmesini, Allah'ın emrettiği şekilde davranmasını, bilmediği hususları ulemadan sormasını (istişare), gaza ve cihat sünnetini devam ettirmesini, daima adaletle davranmasını, düşkünlere ve esirlere iyi muamele etmesini, cömertlik kapısını daima açık tutmasını, reayayı hoş tutmasını, gençlere karşı lütufkâr, yaşlılara karşı hürmetkâr olmasını, hizmetliler ve devlet erkânı üzerinde ihsanını devamlı kılmasını, emaneti ehil olana vermesini, askerlerine daima ihsanda bulunmasını, düşmanlara karşı ferasetli olmasını öğütlemiştir (Kaytaz, 2016: 151-155). Osman Bey’in yönetim yaklaşımının önemli bir kısmını adalet ve halka hizmet anlayışı şekillendirmektedir. Bu yaklaşımın en belirgin göstergesi, hayata geçirdiği vakıflar olmuştur. Osman Bey zamanında yapıldığı kesin olarak tespit edilen 13 vakıf bulunmaktadır (Turgut, 2016: 89). Bu uygulamalar ve oğluna verdiği öğütlerin tamamına yakını, dışlayıcı olmayan bütüncül bir yaklaşımı ifade etmektedir.

\section{SONUÇ}

Anlatı unsurlarını anlaşılır kılma sürecinde, yorumcunun ufku ile ele alınan metinlerin ufku karşılaşmaktadır ve bu karşılaşmadan ne tamamen metinlerin kendisine ne de tamamen yorumcuya ait olan anlamlar ortaya çıkmaktadır (Özlem, 2019: 30). Söz konusu anlaş1lır kılma çabası kapsamında bu makalenin önerme ve araştırma sorusu oluşturulmuştur. Fenomenolojik araştırma deseni kullanılmak suretiyle çıkarımlarda bulunulmaya çalışılmıştır. Kaynak tarama ve bulguları değerlendirme sürecinde ise Osman Bey dönemini ele alan çalışmalar incelenerek değerlendirmeye tabi tutulmuştur.

Osman Bey'in, Porter'ın “Jenerik Strateji” sınıflandırması açısından odaklanma ve farklılaştırma stratejilerini yakınsayan faaliyetler yürüttüğünü öne sürmek mümkündür. Zira Osman Bey, "Batı'ya yönelme” anlayışını sürdürülebilir kılmak için yoğun bir çaba sergilemiştir. Bir başka deyişle Osman Bey bilinçli bir stratejik tercihle Batı seferlerine “odaklanma” gerçekleştirmiş ve yürüttüğü muharebelerinden başarıyla çıkmıştır. Ayrıca, spesifik olarak Batı'ya yönelmesi, diğer Anadolu beylikleri ile onun yaklaşımını belirgin ölçülerde ayırt edici kılmakta ve onun "farklılaştırma" stratejisini yakınsadığı kanaatini 
güçlendirmektedir. Her ne kadar Porter, "maliyet liderliği, odaklanma ve farklılaştırma" şeklinde üçlü bir ayrıma gitmiş olsa ve örgütlerin bu üç stratejiden yalnızca birine odaklanmasının bir zorunluluk olduğunu öne sürse de Osman Bey'in iki farklı stratejiyi de aynı anda gerçekleştirebildiği yürüttüğü başarılı faaliyetlerden anlaşılabilmektedir. Bu kısa anlatımdan da anlaşılabileceği üzere, bu makalenin analize dönük ana başlığının altındaki "büyüme” ve "bütüncül yaklaşım” alt başlıklarının haricinde, stratejik yönetim kavram ve teorileri bakımından ilave pek çok analiz başlığ̣ ortaya koymak olası görünmektedir.

Osman Bey'in yönetsel faaliyetlerinin klasik ve neoklasik gibi modern öncesi, durumsallık ve sistem yaklaşımları gibi modern ve nihayetinde örgüt kuramları gibi modern sonrası birçok çalışma alanı ekseninde ele alınabileceği yargısına ulaşılabilmektedir. Ayrıca bu makale, büyüme stratejisini, kazançlı çıkan taraf açısından ele almaktadır. Konunun, tümüyle karşıt pencereden ele alındığı çalışmaların yürütülmesi de mümkün görünmektedir. Örneğin 19. yüzyıl yazarlarından Daudet (1998a: 13; 52; 143; 1998b: 111-114; 119), kaleme aldığı kısa hikâyelerin büyük bir çoğunluğunda, Prusya'nın Fransa aleyhinde sürekli bir biçimde büyüme stratejisi gütmesi temasını işlemektedir. Dolayısıyla, söz konusu büyüme stratejisinden olumsuz yönde etkilenen Fransız birey ve toplulukları açısından konuya yaklaşılması da farklı bir bakış açısı sunabilme potansiyeline sahiptir.

Osmanlı Devleti'nin kuruluşu, kaynak yetersizliği nedeniyle tartışmalı bir dönem olarak kabul edilmektedir. Bunun bir nedeni, tarihçilerin beylik aşamasındaki döneme önem vermemiş olması, diğer bir nedeni ise 1402'ye kadar toplanan Osmanlı arşivinin Bursa yağması sırasında Timur tarafından yakılmış olmasıdır (Öztuna, 1994: 17). Bu makale açısından bir diğer sınırlılık ise mevcut kaynaklar kapsamında Osman Bey'in faaliyetlerinin, stratejik yönetim alanındaki belirli kavramlar ile çerçevelenmiş olmasıdır. Mikroanalitik bir çalışma olması ve yazım hacmi sınırlaması nedeniyle bu makalenin analize dönük içeriği, "büyüme" ve "bütüncül yaklaşım" gibi ana eksen anlatımlarıyla sınırlandırılmıştır. Bu eksen ya da boyutların yanı sıra, stratejik ittifaklar (evlilik ve müttefiklik ilişkileri sayesinde edinilen kazanımlar) veya zamanlama tercihlerinin, Miles ve Snow gibi teorisyenlerin tipolojileri kapsamında ele alınabilmesi olası görünmektedir. Dolayısıyla, bu makaledeki odaklanmış (niş) çalışma konularının yanı sıra başka türden odaklanılmış çalışma alanlarının fazla oluşu, gelecek çalışmalar için açık bir davet gibi görünmektedir. 


\section{KAYNAKÇA}

Algül, H. (1999). Osman Gazi ve Orhan Gazi’nin şahsiyeti. Uludă̆ Üniversitesi İlahiyat Fakültesi Dergisi, 8(8), 59-73.

Aşıkpaşazade. (1332). Tevarih-i Al-i Osman. İstanbul.

Bağc1, B. (2020). Osmanlı Devleti'nin kuruluş döneminde kalenderî gruplar. Ortaçağ Araştırmaları Dergisi, 3(2), 240-252.

Barca, M. (2005). Stratejik yönetim düşüncesinin evrimi: bilimsel bir disiplinin oluşum hikâyesi. Yönetim Araştırmaları Dergisi, 5(1), 7-38.

Barca, M. (2009). Stratejik yönetim düşüncesinin gelişimi. Ankara Sanayi Odası Dergisi, 3452.

Barkan, Ö. L. (2015). İstila devirlerinin kolonizatör Türk dervişleri ve zaviyeler. Ínsan ve İnsan Dergisi, 5, 5-37.

Başar, T. (2018). Osmanlı kuruluş dönemi'nde hayri-müslimler ile ilişkiler. Yeditepe Üniversitesi Tarih Bölümü Araştırma Dergisi, 2(4), 35-46.

Bracker, J. (1980). The historical development of the strategic management concept. Academy of management review, 5(2), 219-224.

Cezar, M. (1962). Mufassal Osmanlı Tarihi. İstanbul: İskit Yayınevi.

Chandler, A.D. (1962). Strategy and Structure: Chapters in the History of the American Industrial Entreprise, Cambridge, MA: MIT Press.

Cide, Ö. (2014). Osmanlı Kuruluş Döneminde Beylikler ile Olan İlişkilerde Din Faktörü. Sosyal Bilimler Dergisi, 4(7), 99-117.

Cide, Ö. (2015). Osmanlı Devleti’nin kuruluş döneminde meşruiyet sorunu ve ilk kaynaklara yansıması. Kilis 7 Aralı Üniversitesi İlahiyat Fakültesi Dergisi, 2(2), 105-126.

Clausewitz, C. von. (1999). Savaş Üzerine (Çev. H. F. Çeliker). İstanbul: Özne Yayınları.

Creswell, J.W. (2018). Nitel Araştırma Yöntemleri Beş Yaklaşıma Göre Nitel Araştırma ve Araştırma Deseni (Çev. Ed. M. Bütün ve S.B. Demir). Ankara: Siyasal Kitabevi.

Cummings, S. (1993). Brief case: the first strategists. Long range planning, 26(3), 133-135.

Çakıray, A. (2017). Arguments towards the rising of ottoman empire. Yeditepe Üniversitesi Tarih Bölümü Araştırma Dergisi, 1(1), 6-25.

Çekiç, A. (2018). Kuruluş devri Osmanlı diplomasisi ve nitelikleri. Akademik Tarih ve Düşünce Dergisi, 5(16), 243-267.

Danişmend, İ. H. (1971). Osmanlı Tarihi Kronolojisi. İstanbul.

Daudet, A. (1998a). Pazartesi Öyküleri I (Çev. S.E. Siyavuşgil). Çağdaş Matbaacılık Yayıncılık Ltd. Şti.

Daudet, A. (1998b). Pazartesi Öyküleri II (Çev. S.E. Siyavuşgil). Çağdaş Matbaacılık Yayıncılık Ltd. Şti.

Drucker, P. F. (1954). The Practice of Management. Haper e Row.

Evered, R. (1983). So what is strategy? Long range planning, 16(3), 57-72. 
Ferreira, J. J., Raposo, M. L., \& Mainardes, E. W. (2014). Strategy and strategic management concepts: are they recognised by management students? Economics and Management.

Geiger, M. (2015). Estetik Anlayış (Çev. T. Mengüşoğlu). Ankara: Doğu Batı Yayınları.

Güler, C. (2019). Osman Gazi ile İnegöl tekfurunun mücadelesi ve İnegöl’ün fethi. Genel Türk Tarihi Araştırmaları Dergisi, 1(1), 55-68.

İnalcık, H. (1990). Osmanlı devleti'nin kuruluş sorunu (Çev. Tahir Sünbül). Ankara Üniversitesi Dil ve Tarih-Coğrafya Fakültesi Tarih Bölümü Tarih Araştırmaları Dergisi, 15(26), 329-339.

İnalcık, H. (1999). Osmanlı Tarihine Toplu Bir Bakış. G. Eren (Editör), Osmanlı I içinde (s. 37-118), Yeni Türkiye Yayınları.

Kapur, V., Ferris, J., Juliano, J., \& Berman, S. J. (2005). How successful companies challenge conventional wisdom about the limits to growth. Strategy \& Leadership.

Kaytaz, F. (2016). Erken dönem Osmanlı tarih metinlerine göre Osman Gazi'nin Orhan Gazi’ye nasihatleri. FSM İlmî Araştırmalar İnsan ve Toplum Bilimleri Dergisi, 7, 147-163.

Keçecioğlu, T. (2008). Stratejik düşünmedeki keskin viraj ya da soyut varlıkların zaferi: strateji haritaları. Ege Academic Review, 8(2), 469-485.

Kınalızade Ali Efendi, (2010). Devlet ve Aile Ahlakl. İstanbul: İlgi Kültür Sanat Yayınc1lık.

Koçel, T. (2018). İşletme Yöneticiliği (17. Baskı). İstanbul: Beta Yayınları.

Kurtaran, U. (2012). Bir imparatorluğun doğuşu Osmanlı kuruluş dönemi. Gümüşhane Üniversitesi Sosyal Bilimler Elektronik Dergisi, 5, 244-265.

Mintzberg, H. (1967). The science of strategy making. Industrial Management Review, 8(2), $71-81$.

Mintzberg, H., \& Quinn, J. B. (1991). The strategy process: concepts, contexts, and cases (2nd Edition): Prentice Hall.

Musashi, M. (2015). Beş Çember Kitabı (Çev. S. Özbudun). İstanbul: Altın Kitaplar Yayınevi.

Nelson, J. A. (2018). Hayatımızdaki Ekonomi (Çev. Didem Kizen). İstanbul: Yapı Kredi Yayınları.

Özlem, D. (2019). Hermeneutik ve Şiir. İstanbul: Notus Kitap Yayınc1lık.

Öztuna, Y. (1994). Büyük Osmanlı Tarihi. İstanbul: Ötüken Neşriyat.

Porter, M. E. (1985). Competitive Advantage: Creating and Sustaining Competitive Performance. Free Press.

Rothaermel, F. T. (2016). Strategic Management: Concepts (3rd Edition). New York: McGrawHill Education.

Sun Tzu, (1996). Savaş Sanatı (Çev. S. Özbudun ve Z. Ataman). İstanbul: Altın Kitaplar Yayınevi.

Turgut, V. (2016). Osman Gazi'nin kimliği meselesi ve cihanşümûl bir devlete isminin verilmesinin sebepleri üzerine. Akademik İncelemeler Dergisi, 11(1), 83-120.

Turnbull, S. (2012). The Ottoman Empire 1326-1699. Oxford: Osprey Publishing. 
Mersin Üniversitesi Sosyal Bilimler Enstitüsü e-Dergisi

Cilt: 5 Sayı:1/Aralık 2021

Uzunçarşılı, İ. H. (1994). Osmanlı Tarihi Birinci Cilt (6.Bask1), Ankara: Türk Tarih Kurumu Basımevi.

Ülgen, H., \& Mirze, S. K. (2020). Isşletmelerde Stratejik Yönetim (10. Bask1). İstanbul: Beta Yayınları. 